\title{
Pressure to Publish: Laura Terracina and her Editors
}

\author{
Amelia Papworth
}

Laura Terracina (1519-c.1577) was the bestselling female author of sixteenth-century Italy, publishing eight poetry collections, several of which went through numerous reprints. While other female poets attained greater cultural prestige, none was as widely published, nor reflected so well the developing worlds of print, publication, and authorship from mid- to late Cinquecento. Her publication history problematizes the accepted narrative of how women came to print and of their relationship with their editors and publishers. From the time she first appeared in print in 1546 to the writing of her final manuscript in 1577, Terracina proved to be an engaged and headstrong author with a strong sense of ownership of her works. This article will explore Terracina's relationships with her editors and publishers, analyzing her role in the publication process to argue that she took a much more active part in their production than has previously been appreciated.

Unlike other female authors of the period, ${ }^{1}$ Terracina seems to have exercised a degree of influence over how and when her works were published, and strongly believed in her right to assert ownership of those works. The first example of Terracina's poetry

${ }^{1}$ For more on female publication in the sixteenth century, see Virginia Cox, Women's Writing in Italy 1400-1650 (Baltimore: Johns Hopkins University Press, 2008); idem, The Prodigious Muse: Women's Writing in Counter-Reformation Italy (Baltimore: Johns Hopkins University Press, 2011); Diana Robin, Publishing Women: Salons, the Presses, and the Counter-Reformation in Sixteenth-Century Italy (Chicago: University of Chicago Press, 2007); idem, "The Lyric Voices of Vittoria Colonna and the Women of the Giolito Anthologies, 1545-1559," A Companion to Vittoria Colonna, ed. Abigail Brundin, Tatiana Crivelli, and Maria Serena Sapegno (Leiden: Brill, 2016). 
appearing in print dates from 1546, in the form of an ottava in the second edition of Lodovico Domenichi’s Rime diverse di molti eccellentissimi autori. ${ }^{2}$ In 1548 her first sole-authored work was published by Giolito in Venice, a collection of Rime. As the table below shows, Giolito went on to publish Terracina's most popular work, the Discorso sopra tutti li primi canti d'Orlando Furioso (hereafter Discorso).

Editions of Sole-Authored Works by Laura Terracina to 1600

\begin{tabular}{|l|l|l|l|l|l|}
\hline Date & Title & First Publisher & Editor & City & $\begin{array}{l}\text { Reprints (until } \\
\text { 1600) }\end{array}$ \\
\hline 1548 & $\begin{array}{l}\text { Rime de la signora Laura } \\
\text { Terracina }\end{array}$ & Gabriele Giolito & Lodovico & Venice & $\begin{array}{l}1549,1550,1553, \\
1554,1555 / \mathbf{6}^{3}\end{array}$ \\
& & & Domenichi & & $\begin{array}{l}1560(\mathbf{x} 2), \\
1565(x 2)^{4}, \mathbf{1 5 6 6}^{5}\end{array}$ \\
\hline
\end{tabular}

${ }^{2}$ Rime diuerse di molti eccellentiss. auttori nuouamente raccolte. Libro primo (Venice: Gabriel Giolito de' Ferrari, 1545). Terracina’s poem, “Bench'io vi scriva, anchor non vi conosco,/ O Domenichi," was added to the second edition (1546) and will be discussed more fully below. See Tomasi, Franco, and Paolo Zaja, Rime di molti eccellentissimi autori (Giolito 1545) (Turin: Edizioni RES, 2001), 380-81.

${ }^{3}$ Dates in bold are those not given by Virginia Cox, but recorded in library catalogs.

${ }^{4}$ Salvatore Bongi records a 1547 publication of a "libretto" by Terracina in Florence, thanks to evidence of a bookseller's catalog (Annali di Gabriel Giolito de' Ferrari da Trino di Monferrato, stampatore in Venezia [Lucca: Giusti, 1890-95], 227), but I have found no further evidence for this.

${ }^{5}$ The 1566 Giolito edition is a combined edition of the Discorso with the Rime. 


\begin{tabular}{|c|c|c|c|c|c|}
\hline 1549 & $\begin{array}{l}\text { Rime seconde della } \\
\text { signora Laura Terracina } \\
\text { di Napoli, et di diversi a } \\
\text { lei }\end{array}$ & Lorenzo Torrentino & $\begin{array}{l}\text { (Lodovico } \\
\text { Domenichi? } \\
\text { ) }\end{array}$ & $\begin{array}{l}\text { Florenc } \\
\mathrm{e}\end{array}$ & $\mathrm{Nil}^{6}$ \\
\hline 1549 & $\begin{array}{l}\text { Discorso sopra tutti li } \\
\text { primi canti d'Orlando } \\
\text { Furioso }\end{array}$ & Gabriele Giolito & Unnamed & Venice & $\begin{array}{l}1550(\mathrm{x} 2){ }^{7}{ }^{7} \text { rev. ed. } \\
1551,{ }^{8} 1554,1557, \\
1559,1560(\mathrm{x} 2), \\
1561,1564(\mathrm{x} 2), \\
1565,1566,{ }^{9} 1567, \\
1573,1577,1579, \\
1581,1583(\times 2), \\
1588,1598\end{array}$ \\
\hline 1550 & $\begin{array}{l}\text { Quarte rime della Signora } \\
\text { Laura Terracina detta } \\
\text { Phebea nell'Academia } \\
\text { degli'Incogniti }\end{array}$ & $\begin{array}{l}\text { Gio. Andrea } \\
\text { Valvassorio detto } \\
\text { Guadagnino }\end{array}$ & $\begin{array}{l}\text { Giovanni } \\
\text { Alfonso } \\
\text { Mantegna } \\
\text { di Maida }\end{array}$ & Venice & 1551,1560 \\
\hline 1552 & $\begin{array}{l}\text { Quinte rime della signora } \\
\text { Laura Terracina, detta } \\
\text { Phebea nell'Academia de } \\
\text { gl'Incogniti }\end{array}$ & Valvassorio & $\begin{array}{l}\text { Giovanni } \\
\text { Alfonso } \\
\text { Mantegna } \\
\text { di Maida }\end{array}$ & Venice & $1560^{10}$ \\
\hline
\end{tabular}

${ }^{6}$ Torrentino is commonly cited as publisher, but I have found only circumstantial evidence for this. It is plausible that when Domenichi established himself in Florence working with Torrentino, he effectively took Terracina with him.

${ }^{7}$ Bongi states this was published 1549 in fine 1550 (Annali, 269). Cox dates the first edition as 1549 (Women's Writing, 237).

${ }^{8}$ The title was altered in editions after 1550 to Discorso sopra il principio di tutti $i$ canti d'Orlando Furioso.

${ }^{9}$ The 1565 and 1566 Giolito editions combine the Discorso with the Rime.

${ }^{10}$ Cox lists a 1558 edition (Women's Writing, 237) based on its citation in Axel Erdmann ed., "My gracious silence”: Women in the Mirror of $16^{\text {th }}$ Century Printing in Western Europe (Luzern: Gilhofer \& Ranschburg, 1999), 220. However, Mr. Erdmann has kindly confirmed to me that this is an error based on incorrect earlier bibliographical sources. 


\begin{tabular}{|c|c|c|c|c|c|}
\hline 1558 & $\begin{array}{l}\text { Le seste rime della signora } \\
\text { Laura Terraccina [sic] di } \\
\text { Napoli }\end{array}$ & $\begin{array}{l}\text { Vincenzo } \\
\text { Busdragho }\end{array}$ & $\begin{array}{l}\text { Vicenzo } \\
\text { Arnolfini } \\
(?)^{11}\end{array}$ & Lucca & None $^{12}$ \\
\hline 1560 & $\begin{array}{l}\text { Seste rime de la Signora } \\
\text { Laura Terracina } \\
\text { novamente reviste, \& } \\
\text { stampate }\end{array}$ & Raymondo Amato & Unnamed $^{13}$ & Naples & None \\
\hline 1561 & $\begin{array}{l}\text { Settime rime sovra tutte le } \\
\text { donne vedove di questa } \\
\text { nostra citta di Napoli, } \\
\text { titolate e non titolate }\end{array}$ & Mattio Cancer & Unnamed & Naples & None $^{14}$ \\
\hline 1567 & $\begin{array}{l}\text { La seconda parte de' } \\
\text { discorsi sopra le seconde } \\
\text { stanze de' canti d'Orlando } \\
\text { furioso, della s. Laura } \\
\text { Terracina detta } \\
\text { nell'Academia de } \\
\text { gl'Incogniti, Febea }\end{array}$ & Valvassorio & Unnamed & Venice & 1584 \\
\hline
\end{tabular}

${ }^{11}$ In the dedication to her 1560 Seste rime, Terracina names Arnolfini as her contact in Lucca who solicits her work for publication. Whether he carried out editorial work is unclear.

12 This is a pirated edition for which Terracina supplied poetry, but which was published without her knowledge or financial benefit.

${ }^{13}$ Following her negative experience with the "unauthorized" 1558 edition of the Seste rime, Terracina shows greater independence from male editors, as discussed later in the article.

${ }^{14}$ Bongi dates this work to 1560 (Annali, 455). Since it appears to have been published in one edition dated 1561, and with a dedication dated the end of that year, most likely Bongi's second-hand information was incorrect, and Cox reproduced it (Women's Writing, 238). 
The final known piece of work by Terracina is an unpublished, partially autograph manuscript dated 1577, containing a selection of encomiastic and religious poetry, with the dedication signed at Chiaia, just outside Naples. ${ }^{15}$

As is evident from the table, Terracina's publication trajectory was peripatetic, extending from Venice to Florence to Naples, with successful works such as the Discorso, printed twenty-three times in the century, followed by highly local works such as the Settime rime, explicitly addressed to a Neapolitan readership. The list of published works is notable too for its unusually long time span: Terracina wrote from the 1540s, a time of dynamism in the publishing industry and relatively propitious for women writers, until the 1570 s, when the Counter-Reformation began to shape the themes and forms of literature. ${ }^{16}$ Her three decades of publication history strongly suggest that Terracina promoted the printing of her works, in

15 "Sonetti Al sommo Pontefice Gregorio Decimo terzo . . Libro Nono" (hereafter Nono libro) in the Biblioteca Nazionale Centrale di Firenze, MS Palatino 229.

${ }^{16}$ For more on the period $1540-60$ as a time of cultural vitality, see Carlo Dionisotti, "Italian Literature in the Age of the Council of Trent," Geografia e storia della letteratura italiana (Turin: Einaudi, 1999), 227-54. Dionisotti's hypothesis that women were marginalized from the literary world after this point has been challenged by, for example, Cox, who argues that the Counter Reformation fostered women's writing in certain acceptable genres such as religious lyric, while encouraging their spread into diverse genres and milieus (Women's Writing, 121-65). For more on the effect of the Counter-Reformation on literature and women's writing, see Cox, The Prodigious Muse; Robin, Publishing Women, 199-204, and Robin, "The Lyric Voices." 
contrast to other well-known female authors of the Cinquecento. ${ }^{17}$ Moreover, her extensive publication suggests a receptive readership for her works that encouraged publishers to work with her. Even her final manuscript, ${ }^{18}$ which contains a section of rime spirituali ostensibly disconnected from worldly concerns, also includes encomiastic poetry. While other female poets, from Vittoria Colonna (1490-1547) to Tullia d'Aragona (c.1510-56), had shown a more circumspect attitude towards print publication, Terracina displays no such hesitation. ${ }^{19}$ In addition, she was a publicly celebrated member of the Neapolitan Academia degli Incogniti, a rare honor at a time when few women were admitted into literary academies, in which their specific participation remains unclear. ${ }^{20}$

${ }^{17}$ Although Vittoria Colonna never actively promoted the printing of her works, thirteen or fourteen sole-authored editions of her poetry were published during her lifetime. This publication history suggests that Colonna, who was close friend of some of Venice's most prominent editors, was aware of her status as a commercial asset. See Tatiana Crivelli, “The Print Tradition of Vittoria Colonna's Rime," Brundin, Crivelli, and Sapegno, A Companion to Vittoria Colonna, 69-139. The sole-authored poetry collections of other wellknown women such as Veronica Gambara were only published posthumously.

18 1577, Biblioteca Nazionale Centrale di Firenze, MS Palatino 229.

${ }^{19}$ For more on Colonna, see Brundin, Crivelli, and Sapegno, A Companion to Vittoria Colonna; on Tullia d'Aragona, see the introduction to Tullia d'Aragona, Dialogue on the Infinity of Love, ed. Rinaldina Russell (Chicago: University of Chicago Press, 1997).

${ }^{20}$ Terracina's membership in the Neapolitan Academia degli Incogniti (not the Venetian institution of the same name) dates from around 1546, the year of its foundation. She adopted the pseudonym Febea, the name given to Diana as the carrier of the light of the moon, and is referred to as such in the titles of her later publications, as the table above 
To date, not only has criticism of Laura Terracina been largely negative, but it has failed to appreciate her significance for the history of sixteenth-century publishing, and in particular the history of women's writing in that century. Three monographs, an early twentieth-century essay, assorted bibliographical notices on rare editions, a tesi di laurea, and two book chapters make up the critical work on Terracina, supplemented by a number of biographical encyclopedia entries and shorter references. ${ }^{21}$ Given that Terracina was, by

shows. See Michele Maylender, Storia delle accademie d'Italia (Bologna: A. Forni, 192630), 3:202-3. For more on women in Cinquecento academies, such as Laura Battiferra and Veronica Gambara, see Virginia Cox, "Members, Muses, Mascots: Women and Italian Academies," The Italian Academies 1525-1700: Networks of Culture, Innovation and Dissent, ed. Jane E. Everson, Denis V. Reidy, and Lisa Sampson (Oxford: Legenda, 2016), 132-69.

${ }^{21}$ See Benedetto Croce, "La casa di una poetessa" (1901), Storie e leggende napoletane (Bari: Laterza, 1948), 275-89; Lina Maroi, Laura Terracina: poetessa napoletana del secolo XVI (Naples: Francesco Perella, 1913); Angelo Borzelli, Laura Terracina: poetessa del Cinquecento (Naples: M. Marzano, 1924); and Luigi Montella, Una poetessa del Rinascimento: Laura Terracina, con le None rime inedite (Salerno: EdisudSalerno, 1993). Rossanna di Stefano's tesi di laurea "Ricerche su Laura Terracina, petrarchista napoletana" (Università degli Studi di Roma, Facoltà di Lettere e Filosofia, 1974-75) is cited in Deanna Shemek's chapter, “Getting a Word in Edgewise,” Ladies Errant: Wayward Women and Social Order in Early Modern Italy (Durham: Duke University Press, 1998), 126-57, 230 n1. Shemek’s chapter and Gerry Milligan’s “Proving Masculinity Before Women: Laura Terracina and Chiara Matraini Writing on Warfare," The Poetics of Masculinity in Early Modern Italy and Spain, ed. Milligan and Jane Tylus (Toronto: Centre 
some margin, the highest-selling female author of the sixteenth century, ${ }^{22}$ and in view of the critical interest in female-authored works in the last thirty years, ${ }^{23}$ such a dearth of interest is astounding. It is also surprising given Terracina's close association with some of the most illustrious names of Cinquecento publishing: her works were published by Giolito and Valvassori and edited by Domenichi; she exchanged poetry with Benedetto Varchi, Luigi Tansillo, and Fabio Ottinello, among others. ${ }^{24}$ Even when Terracina's links to important literary figures have been acknowledged, her agency and determination in her interaction with them have been underestimated. Terracina grasped the potential of the press to grant her

for Reformation and Renaissance Studies, 2010), 185-212, both helpfully emphasize literary and thematic analysis over biography. See also Caroline Isabel Milvain Waring, "The Reception of Ariosto's Orlando furioso (1532) by Three Italian Women Writers of the Sixteenth Century" (Ph.D. diss., University of Oxford, 2006); and for details on form, see Rosa Casapullo, “Contatti metrici fra Spagna e Italia: Laura Terracina e la tecnica della glosa," Atti del XXI congresso internazionale di linguistica e filologia romanza, ed. Giovanni Ruffino (Tübingen: Neimeyer, 1998), 18-24.

${ }^{22}$ Vittoria Colonna's Rime (1538) went through fourteen editions and her Rime spirituali (1543), four editions by 1600 (Cox, Women's Writing, 236); in total, Terracina had forty-three editions between 1548 and 1600, plus one pirated edition. Other famous female poets, such as Veronica Gambara, never enjoyed a sole-authored edition in their own lifetime. ${ }^{23}$ See for example, Pamela Joseph Benson, The Invention of the Renaissance Woman (University Park: Pennsylvania State University Press, 1992); Cox, Women's Writing; Margaret L. King, Women of the Renaissance (Chicago: University of Chicago Press, 1991); Monica Farnetti and Laura Fortini, Liriche del Cinquecento (Rome: Iacobelli Editore, 2014).

${ }^{24}$ See, for example, Terracina, Seconde rime and Quinte rime. 
power and cultural authority, and to possibly earn her money, and she therefore exploited the system to her own benefit.

\section{Lodovico Domenichi: Launching a Career}

Laura Terracina's first editor was Lodovico Domenichi (1515-64), the Venetian poligrafo who shepherded to press an extraordinary number of works in the mid-sixteenth century, many of them authored by women. ${ }^{25} \mathrm{He}$ was responsible for the first major anthology of contemporary lyric poetry, Rime di molti eccellentissimi autori (1545), which launched a fashion for anthologies. He oversaw a number of anthologies in the unofficial series - canny publishers would simply label their own anthology with the next appropriate numberincluding a collection of female-authored verse, Rime diverse d'alcune nobilissime, et virtuosissime donne. ${ }^{26}$ The majority of his editorial work while in Venice was carried out in collaboration with the far-sighted printer of vernacular texts, Gabriel Giolito, with Domenichi overseeing eighty-six works for him. ${ }^{27}$ Domenichi seems to have acted as a mentor to Terracina, publishing her first work in his edited anthology of 1546, before writing the

${ }^{25}$ For more on Domenichi and Giolito, see Amedeo Quondam, “"Mercanzia d'onore,' 'Mercanzia d'utile.' Produzione libraria e lavoro intelletuale a Venezia nel Cinquecento,' Libri, editori e pubblico nell'Europa moderna. Guida storica e critica, ed. Armando Petrucci (Rome and Bari: Editori Laterza, 1977), 51-104; and Bareggi, Il mestiere di scrivere.

${ }^{26}$ Lucca: Vincenzo Busdragho, 1559. For more on this work, see Deanna Shemek, “The Collector's Cabinet: Lodovico Domenichi’s Gallery of Women,” Strong Voices, Weak History: Early Modern Women Writers and Canons in England, France, and Italy, ed. Pamela Joseph Benson and Victoria Kirkham (Ann Arbor: University of Michigan Press, 2005), 239-62; Robin, “The Lyric Voices,” 455-62; and Robin, Publishing Women, 238-42.

${ }^{27}$ Bareggi, Il mestiere di scrivere, 283. 
dedication to her first sole-authored volume in 1548 . Once she had become established as a popular writer, however, their relationship cooled, as Terracina reports in the lyric poetry discussed below.

Terracina's first published poem was not only included in an anthology produced by Domenichi, it was also explicitly addressed to him. In 1546, Domenichi oversaw a second edition of his popular Rime di molti eccellentissimi autori $;{ }^{28}$ he made a number of additions, including the poem "Bench'io vi scriva, ancor non vi conosco" by Terracina. ${ }^{29}$ While highly celebratory of Domenichi, the poem also functions as a subtle manifesto for Terracina herself:

Bench'io vi scriva, ancor non vi conosco,

O DOMENICHI mio chiaro e divino,

Ma da Vinegia fin qui suona il tosco

Vostro leggiadro stile e pellegrino, [...]

E benché donna io sia, contra il desio,

Adoro i dotti e gli scrittori anch'io. (Tomasi and Zaja, Rime, 380) ${ }^{30}$

(Although I write to you, I do not yet know you,

Oh my bright, divine Domenichi,

But from Venice to here rings out

Your graceful, wandering Tuscan style, [...]

And although I am a woman, contrary to desire,

\footnotetext{
${ }^{28}$ Venice: Giolito, 1545.

${ }^{29}$ Tomasi and Zaja, Rime, 380-81.

${ }^{30}$ I have modernized the spelling of the poems.
} 
I too adore wise men and writers. $)^{31}$

She makes no attempt to conceal or downplay her gender, but rather defiantly asserts that it does not her hamper her will to learn. In a sonnet that functions as a risposta to her poem in ottava, Domenichi lauds Terracina as a source of civic pride and sufficiently talented to instill inspiration in him:

Lauro gentil, le cui leggiadre frondi

Danno a l'umil Sebeto onore e gloria,

Mentre hai del tempo e de l'oblio vittoria

Co i frutti, che non sempre al mondo ascondi,

Tanto nel petto mio valor infondi

Che de le lodi tue tesser istoria

Dato mi sia. ${ }^{32}$

(Gentle laurel, whose graceful fronds

Lend honor and glory to the humble Sebeto,

While you have victory over time and oblivion

With the fruits, which you do not always reveal to the world,

You impart such valor to my heart,

May I be given the task of weaving a story of your praises.)

\footnotetext{
${ }^{31}$ All translations are my own.

${ }^{32}$ Ibid., 395.
} 
Their relationship led to Domenichi writing the dedication to Terracina's first published volume, the Rime de la signora Laura Terracina, which was also published by Giolito. Domenichi's public praise of the poet established him as her "guarantor," supervising the entry of a female author into the public sphere. There was precedent for such a relationship in the role Pietro Bembo played for the major female authors before Terracina in sixteenthcentury Italy, Vittoria Colonna and Veronica Gambara. ${ }^{33}$ Bembo included poetry by both women in the second edition of his first published book of Rime,${ }^{34}$ and his public display of verse exchange with them confirmed their poetic status. It could be that Domenichi and Terracina hoped to model their relationship on this mutually beneficial collaboration. At first, Domenichi himself admitted that his attitude towards Terracina's poetry was somewhat unenthusiastic, and that her verse remained neglected for "several months sheltering in my poor lodging, although I, according to my own poor judgment, had kept them with care and placed them aside, indeed above all my dearest things." ${ }^{35}$ Domenichi claims, however, that upon closer inspection the poems showed their merit and affirms his personal affinity with the topics they treat: "Because I took their arguments well, and beginning to recognize their worth along with my own state, and where they came from and where they had ended up, I

${ }^{33}$ Veronica Gambara, Complete Poems, ed. Molly M. Martin and Paola Ugolini (Toronto: Iter / Centre for Reformation and Renaissance Studies, 2014), 2-3.

${ }^{34}$ Delle rime di m. Pietro Bembo (Venice: Giovann'Antonio de Nicolini da Sabio, $1535)$.

35 “parecchi mesi albergato nel mio povero soggiorno; anchora ch'io l'havessi, secondo il mio poco giudicio, assai bene alloggiate e poste a lato, anzi sopra tutte le mie piu care cose" (Discorso [1550], 2r-v). 
decided myself to give them no more reason to complain about me." ${ }^{36}$ Indeed, such is the merit of Terracina's poetry that in publishing it, Domenichi believes he will "preserve ... [his] reputation with men of judgment," 37 a claim suggestive of how a woman's writings can function as an object of exchange in a homosocial literary economy. ${ }^{38}$ Terracina herself is not entirely absent from this dedication, however, as her permission to publish is assumed: "I am certain that as I received them in my hands thanks to her courtesy, I could also do as I wished with them with her tacit license." ${ }^{39}$ Although Domenichi makes the typical reference to Terracina's reticence towards publication, her interest in seeing her work printed is acknowledged.

Over time, however, the relationship between Terracina and Domenichi seems to have waned. Rather than attempting to hide this fact, Terracina shows no shame at having been spurned by a prestigious male poligrafo; rather, she openly publicizes their increasing

36 "Perche io preso in buona parte le querele loro, e cominciando a conoscere il grado di quelle insieme col mio stato, e onde vengono e ove si son fermate, ho conchiuso fra me medesimo di non dar piu loro cagione di lamentarsi di me” (Ibid., 2v)

37 “conserva . . . la riputation mia con gli huomini di giudicio" (Ibid., 2v).

${ }^{38}$ On women as objects of exchange between men in processes of homosocial bonding, see Gayle Rubin, “The Traffic in Women: Notes on the 'Political Economy' of Sex," Toward and Anthropology of Women, ed. Rayna R. Reiter (New York: Monthly Review Press, 1975), 157-210.

39 “che havendole io havute in mano per sua cortesia, io habbia anco potuto con tacita licenza di lei farne il voler mio." (Discorso [1550], 3r-v). 
distance. In the Quarte rime, she declines to admonish him for his coolness, acting equally aloof towards him:

Per una vostra intendo, e veggio aperto

Lodovico gentil con quanto sdegno

Mostrate in me l'accorto, e dolce ingegno

Et date al buon voler contrario merto [...]

Onde s'io non vi scrivo come soglio

Ragione è ben c'ho visto il pensier vostro

Farsi ad un tratto di molle acqua scoglio. (Quarte rime, 34 r)

(From one of your poems I hear and clearly see

Noble Ludovico, with how much disdain

You merit from me rational and sweet wit

And give good will its opposite value. [...]

So that if I do not write to you as I used to,

The reason is that $\mathrm{I}$ have seen your thoughts

Turn from soft water to hard rock.)

Notably, Terracina is not included in Domenichi's 1559 anthology of women's poetry, Rime diuerse d'alcune nobilissime, et virtuosissime donne. ${ }^{40}$ It has been suggested that this was to avoid saturating the market with Terracina's work, ${ }^{41}$ an argument that seems plausible in light

${ }^{40}$ Venice: Giolito, 1559.

${ }^{41}$ Robin, Publishing Women, 60. 
of the fact that Chiara Matraini, another of Domenichi's protégés, was also excluded from the collection.

\section{Marcantonio Passero: A Constant Presence}

Despite her seeming enthusiasm for publication, Terracina was dependent on male collaborators in a number of ways, not just for editing, but also for accessing centers of publication. A single woman in Naples, she needed the assistance of the Neapolitan bookseller and talent scout Marcantonio Passero to establish publication networks in Venice. There is evidence that before his imprisonment and trial as a heretic in 1575 , Passero also worked with Chiara Matraini and performed a similar role for her, as well as facilitating the publication of the poetry of Isabella di Morra after her death. ${ }^{42}$

Already in Terracina's 1548 Rime, a letter at the end of the volume signed "Il Caudio" describes how the letter's author felt "struck in Passero's bookshop" by the skill of

${ }^{42}$ Matraini mentions Passero in a letter. See Chiara Matraini, Selected Poetry and Prose: A Bilingual Edition, ed. and trans. Elaine Maclachlan, introd. Giovanna Rabitti (Chicago: University of Chicago Press, 2007), 20; Chiara Matraini, Rime e lettere, ed. Giovanna Rabitti (Bologna: Commissione per i Testi di Lingua, 1989), 183. For more on Passero, see Pasquale Lopez, Inquisizione stampa e censura nel regno di Napoli tra '500 e ‘600 (Naples: Edizioni del Delfino, 1974), 99-105. Passero was also responsible for providing Lodovico Dolce with Isabella di Morra's ten sonnets and three canzoni to be included in Rime di diversi illustri signori napoletani, e d'altri nobiliss. Intelletti: nuovamente raccolte, e non più stampate. Terzo libro (Venice: Gabriel Giolito de' Ferrari et fratelli, 1552). For more on Morra, see Alessandra Dagostini, Degno il sepolcro, se fu vil la cuna: L'universo poetico di Isabella Morra (Naples: Nicola Longobardi Editore, 2011). 
Terracina's work. ${ }^{43}$ The letter is signed December 23, 1546, suggesting that Terracina had already been a presence on the Neapolitan literary scene for some years before being published. This letter faces a poem in ottava by Luigi Tansillo, one of Naples' most renowned poets, addressed to Terracina in which he praises her poetry, and again credits Passero with her discovery:

A quel Passer gentil, dentro al cui nido

S'odon dolce cantar si vari augelli,

Poi ch'ei mi fe primier su questo lido

Sentire il suon de vostri accenti belli (Rime, n.p.)

(To that gentle Passero [sparrow], in whose nest

Is heard the sweet singing of so many songbirds,

Since he caused me first on this shore

To hear the sound of your sweet tones.)

In the Seconde rime (1549), Terracina herself draws attention to the central role that Passero played in bringing her works to press:

Voi mi spingete, o Passero gentile,

A publicare i miei cotanti errori (Seconde rime, 47-48)

(You push me, oh noble Passero,

To publish my many errors)

43 “abbattuto ne la libraria del Passero," Rime, 1548, n.p. 
In later works, as Terracina continues to interact with Passero, he appears to push her towards publication in an active way, as the Seste rime (1560) and the Seconda parte de' discorsi (1567) show. The Seste rime, published in 1560, has an unusual endnote, thanks to its status as an authorized edition of Terracina's poetry, unlike the pirated Seste rime published two years prior in Lucca. As Terracina explains in the endnote addressed to Cola Antonio Caracciolo, she had sent her poetry to one Vincenzo Arnolfini, a Lucchese businessman, having been encouraged to do so by her husband, Polidoro Terracina, Passero, and a third party, Martin Picchinucci. After sending her poetry to Lucca with a trusted friend, she heard nothing more for over a year, despite sending frequent letters. She indignantly recounts the end of the story:

I hear, and not even from him, that he had sent it to press, under the name of the noble Isabetta della Rovere, Marchioness of Massa; and I find it in the hands of a gentleman friend of mine, who knew nothing of this, with a new letter and four sonnets, the first in praise of the aforementioned lady, which are not mine ... your excellency can comprehend how the aforementioned Messer Vicenzo embarrassed me, and in what way I ended up taunted and defrauded by him. ${ }^{44}$

44 “intendo, e non già da lui, che l'habbia mandata in stampa, sotto il nome della inclita Isabetta della Rovere Marchesana di Massa; e la ritrovo in mano d'un gentil'huomo mio amico, il quale non sapea nulla di questo, con una nuova epistola \& quattro sonetti, i primi in lode di detta signora, i quali non sono miei . . . può vostra Eccellentia comprendere come il detto Messer Vicenzo m'habbia ben concia, et in che modo io sia rimasta schernita e defraudata da lui" (Seste rime (1560), n.p.). 
Terracina's work had been published under her own name, but with added sonnets that she had not written and an additional dedication to the Marchioness of Massa. Terracina's ire at being cheated out of what she considered her rights as an author is palpable. She clearly considered the work her own, but it was thanks to "the prayers of Messer Marc'Antonio Passero and Signor Polidoro Terracina drawn with great force by Messer Martin Picchinucci" 45 that she claims to have originally sent the work away to Lucca for publication.

In the Seconda parte de' discorsi, the pressure to publish appears to take a more sinister turn. In the dedication to the work, not only does Terracina scathingly defend her own poetic ability, but she insists that she no longer wishes to write, and only does so because a woman has no choice but to obey her husband:

Having come to Naples Messer Luigi Valvassori entreated Signor Polidoro Terracina to entreat me; indeed, if possible, to force me to continue to write I discorsi sopra le seconde stanze de i principii de i canti del Furioso, having already brought to light the first discorsi on the first canti. But I, for the reason above, did not want to employ my pen again in such a manner in any way ... Being thus entreated by the aforementioned Signor Polidoro, I put all deliberation aside and being, as you know, the entreaties of a husband express orders to their wives, I was forced against every wish of my own to follow his will. ${ }^{46}$

\footnotetext{
45 “i prieghi di Messer Marc'Antonio Passero e del signor Polidoro Terracina tirati da un gran sforzo di Messer Martin Picchinucci”

46 “Venuto in Napoli Messer Luigi Valvassori pregò il Signor Polidoro Terracina, che mi dovesse pregare, anzi, se possibil [sic] fosse, sforzarmi ch'io dovessi seguitar di far i discorsi sopra le seconde stanze de i principii de i canti del Furioso, havendo già dato in luce
} 
While Polidoro Terracina and, interestingly, the well-known publisher, Luigi Valvassori, seem to have played the most important role in encouraging composition, we are also told that Marc'Antonio Passero still appears to be working as an unofficial literary agent in Naples, placing Terracina in contact with her dedicatee, Franco Larcari. ${ }^{47}$

Finally, the close relationship between Terracina and Passero is highlighted by the unusual copy of the 1548 Rime and 1550 Discorso bound together and held at the British Library in London: two pages have been pasted in the front of the work, printed in the same font on the same paper, but inexpertly cut to a different size. ${ }^{48}$ The first page is a letter addressed to Marc'Antonio Passero from "Il Doni Fiorentino," namely, Anton Francesco Doni; the second page consists of a sonnet from "Lodovico D.," likely Domenichi and not Dolce. Domenichi and Doni, until 1548, worked closely together, and both were members of

li primi fatti sopra le prime. Ma io per la ragion sudetta non voleva altrimenti por la penna a tal esercitio in modo alcuno ... Essendo dunque pregata dal detto Signor Polidoro c'havessi posto da parte ogni deliberatione et essendo, sapete, le preghiere de gl'huomini espressi comandamenti alle lor donne, mi fu forza contra ogni mia voglia di seguire il voler suo" ( $\mathrm{La}$ seconda parte de' discorsi, n.p.).

${ }^{47}$ There are other cases of male literati playing the role of literary agents for female authors, such as Benedetto Varchi fostering the literary careers of Laura Battiferra and Tullia d'Aragona (Robin, “The Lyric Voices,” 449). Terracina's dedicatee Franco Larcari remains an enigma: the dedication appears to suggest he is in some way an imperial envoy to, or in, Naples, but further biographical information has not been found.

${ }^{48}$ British Library shelfmark: General Reference Collection 241.e.12.(2), n.p. 
the Accademia Ortolana in Piacenza since $1543 .{ }^{49}$ In 1548 they quarrelled, with Doni eventually denouncing Domenichi as a heretic, which led to the latter's imprisonment. In the first 1550 Giolito edition of his Medaglie, Doni includes a medaglia of Domenichi labelled "of alchemy": Domenichi was a false medal, as he was false friend. ${ }^{50}$ In the second Giolito edition of 1550, Domenichi is expunged. Thompson suggests that the 1548 rupture between Doni and Domenichi was not final. In fact, the last break between them must have happened shortly after completion of the first 1550 edition, which includes Domenichi's portrait and several poems by him, but concludes with the list characterizing Domenichi as a false metal. ${ }^{51}$ Taking into account the relationship that existed in the public eye between Terracina and Domenichi (and the frosty relationship between Terracina and Dolce that would later become public), the fact that Domenichi had previously composed poetry in praise of

${ }^{49}$ Wendy Thompson, “Antonfrancesco Doni’s Medaglie," Print Quarterly 24.3 (Sept. 2007): 223-38, 231-32; Paul F. Grendler, Critics of the Italian World 1530-1560: Anton Francesco Doni, Nicolò Franco \& Ortensio Lando (Madison: University of Wisconsin Press, 1969). Although Doni and Lodovico Dolce also knew each other- in 1549, Doni helped to found the literary group the Accademia Pellegrina, whose first members included Dolcehere Dolce is unlikely to be the author.

${ }^{50}$ Thompson, "Medaglie,” 231.

${ }^{51}$ Ibid., 231-32. Thompson notes that this extremely rare first 1550 edition survives in only one copy, at the Biblioteca Marciana in Venice. This edition seems the likely source for the pages bound with the British Library copy, based upon bibliographical information in Cecilia Ricottini Marsili-Libelli, Anton Francesco Doni. Scrittore e stampatore (Florence: Sansoni Antiquariato, 1960), 58. 
Terracina, and the inclusion of his poetry in the first 1550 edition of the Medaglie, Domenichi seems the most likely "Lodovico D.," despite the conflict with Doni.

The third page is a portrait of Terracina. The letter to Passero from Doni describes the scene: Doni is publicly presenting Passero with a portrait of Terracina from a series of woodcut portraits by Enea Vico, commissioned by Doni to be published as Medaglie di Doni. ${ }^{52}$ Doni circulated samples of the woodcut portraits before publication, but given the additional written material, this page was likely cut from the first of the two Giolito editions of this work from $1550 .{ }^{53}$ The editions were published in quarto format, which would also explain why the page bearing the portrait was cut down, but is not the same size as the octavo volumes with which it is bound.

Doni was a key figure in popularizing biographies illustrated with portraits, ${ }^{54}$ and a number of women's poetry collections were also prefaced by a portrait of their author or a pious female figure. ${ }^{55}$ Of the nine medals in the first part of Medaglie, Terracina's is in silver, as a member of the minor nobility and one of four living authors included. Doni's decision to dedicate the portrait to Passero demonstrates how closely bound Passero and Terracina were

${ }^{52}$ For more on the Medaglia series, see Thompson, “Antonfrancesco Doni’s

'Medaglie'; Doni, La prima parte de le medaglie del Doni. Con alcune lettere, d'huomini illustri nel fine, et le risposte (Venice: Gabriel Giolito de Ferrari, 1550).

${ }^{53}$ Thompson, “Antonfrancesco Doni’s 'Medaglie,”' 224-25, 232; Ricottini MarsiliLibelli, 58.

54 Thompson, “Antonfrancesco Doni’s 'Medaglie,”, 223.

${ }^{55}$ Vittoria Colonna and Veronica Franco were, for example, two very different female authors whose works included their portraits. 
in the public imagination. ${ }^{56}$ Both Doni and Passero were very active on the Venetian editorial scene in mid-century, and Doni's presentation to Passero is indicative of the latter's importance as a literary agent. The text of the dedicatory letter from Doni to Passero is highly laudatory, as would be expected:

It is a duty that to your kind spirit be presented the portrait of the medal of that famous lady, illustrious soul, Laura Terracina, who with her works flies through the years of the eternal centuries. Thus you, most noble Passero, will accept this effigy, small in design but great in virtue. ${ }^{57}$

This gift is another example of a woman's writings or the woman herself being passed, literally or metaphorically, from man to man in a homosocial literary economy. Although Domenichi was among the other figures reproduced in a portrait, it was Passero to whom Doni chose to pass the picture of Terracina. This might have been due to the Neapolitan link between Passero and Terracina, and because it was a means to draw Passero into the triangle of Terracina's praise, with Domenichi's poem as the third element. It also provided a

${ }^{56}$ Doni and Terracina's friendly relationship is also evinced by the entry he wrote about her in his Libraria, in which he claims she is a source of light for Naples (La Libraria, [Venice: Gabriel Giolito de' Ferrari, 1558]; edition consulted, ed. Vanni Bramanti [Milan: 1972]).

57 “Egl'è dovere che si presenti alla gentilezza del vostro animo il ritratto della medaglia, di quella famosa donna, Illustre spirito della Signora Laura Terracina, la quale con l'opere sue vola a gl'anni de secoli eterni. Voi adunque Passero nobilissimo accetterete la picciola effigie di disegno e si grande di virtù" (Discorso [1550], n.p.). 
valuable opportunity for Doni to affirm the positive relationship between himself and Passero.

Unfortunately, it is unknown when this portrait of Terracina with accompanying poem and letter were bound together with a copy of the 1548 Rime and 1550 Discorso. In the sixteenth century the high cost of binding meant that similar works or works by the same author were often bound together, and publishers might also make this practice easier for readers by producing compendium works, as shown by the 1566 edition of the Rime combined with the Discorso. ${ }^{58}$ The inclusion in these books of portraits of female authors was also popular, clearly being considered an effective way to boost sales, allowing the reader a titillating glimpse of the female author and her male coterie. ${ }^{59}$ The fact that, at some point between the sixteenth and nineteenth centuries, a collector has deemed it worthwhile to unite these works by Terracina is nonetheless suggestive of her status as a collectible author whose works were not merely read in isolation, but seen as a unitary whole. Clearly, publishers in the sixteenth century saw her in a similar light, responding to a perceived gap in the market by producing these combined editions of Terracina's most popular works.

${ }^{58}$ The work is entitled Rime della Signora Laura Terracina. Con il Discorso sopra il principio di tutti i canti d'Orlando Furioso (Venice: Gabriel Giolito de' Ferrari, 1566). The 1566 Giolito compendium edition of the Rime and Discorso is of the same edition and printing as copies dated 1565, according to the Manchester University Library catalogue, barcode RAEQH.

${ }^{59}$ I have identified four different portraits of Terracina, first used in the Rime (1548), Seconde rime (1549), and Quarte rime (1550) respectively, in addition to the Vico woodcut. For more on the use of female portraits in early modern books, see Robin, Publishing Women, 54-56. 


\section{Lodovico Dolce: A Failed Collaboration}

Along with Lodovico Domenichi, Lodovico Dolce was one of sixteenth-century Venice's most prolific poligrafi, working closely with Gabriele Giolito for a number of years and promoting the literary careers of a number of women. ${ }^{60}$ In Terracina's case, however, the relationship seems to have foundered scarcely after it began, displaying Terracina's own emotional and intellectual investment in the publication of her work. From the Quarte rime (1550) and later editions of the Discorso, the reader learns that Terracina had tried to recruit Lodovico Dolce as an editor for the Discorso itself, but without success.

First, however, it is worth considering why Terracina sought Dolce as an editor in and around 1549, given that Ludovico Domenichi had overseen the Rime (1548) to press and likely the Seconde rime (1549). Although the latter work bears no explicit debt to Domenichi, its probable publication by Torrentino, at a time when Domenichi had moved to Florence and was collaborating with Torrentino, suggests his influence in placing the work. ${ }^{61}$ As Bareggi notes, the 1550s saw Domenichi expand his work in Florence with a subsequent diminution

\footnotetext{
${ }^{60}$ Dolce oversaw the publication of 184 texts for Giolito in their years of
} collaboration, 1542-68 (Bareggi, Il mestiere di scrivere, 286). For more on Dolce, see the introduction to Lodovico Dolce, Dialogo della instituzion delle donne, secondo li tre stati che cadono nella vita umana, ed. Helena Sanson (Cambridge: Modern Humanities Research Association, 2015).

${ }^{61}$ For more on Torrentino, see Domenico Moreni, Annali della tipografia fiorentina di Lorenzo Torrentino (Florence: N. Carli, 1811); and C. Di Filippo Bareggi, “Giunta, Doni, Torrentino: tre tipografi fiorentini fra Repubblica e Principato," Nuova rivista storica 58 (1974): 318-48. 
of his Venetian output; he did not publish an edition in Venice from 1550 until $1555 .{ }^{62}$ By contrast, Dolce was Giolito's primary editor in the 1540s and 1550s and had a reputation for being prolific. ${ }^{63}$ Moreover, he was strongly associated with allegorizations and rewritings of Ariosto's Orlando Furioso, and had worked for a number of years to achieve its canonization through emphasis on its didactic intent. ${ }^{64}$ Terracina was pursuing a similar project in her expansion of the themes of Ariosto's proemial cantos to underline their social and moral import, so Dolce seems to have been logical choice of editor for her.

As a result, it must have been all the more surprising to Terracina when he proved to be such a disappointment as her editor. She makes her anger on the matter quite clear in the Quarte rime (1550) in the first of the work's dedications addressed by Terracina to Giovanni Alfonso Mantegna di Maida, another man of letters:

I believe you know how much well-justified displeasure I have with Messer Lodovico Dolce, sweet to others but more than bitter to me. For, having shown to me in many of his letters his willingness to correct my third published work on the canti

${ }^{62}$ Il mestiere di scrivere, 71-72.

${ }^{63}$ Daniel Javitch, Proclaiming a Classic: The Canonization of Orlando Furioso (Princeton: Princeton University Press, 1991), 33. A number of well-known figures even approached Dolce for help in entering the Venetian literary scene. See Ronnie H. Terpening, Lodovico Dolce, Renaissance Man of Letters (Toronto: University of Toronto Press, 1997).

${ }^{64}$ Javitch, Proclaiming a Classic, 11, 33-34. 
of Ariosto, not only did he not correct it but God would at least want it printed the same as I sent it and not worse. ${ }^{65}$

Terracina here claims that Dolce himself offered to edit her work in his correspondence with her, an offer she gratefully took up. Later editions of the Discorso also contain a lengthy lament against Dolce in the form of a second dedication, added to the collection in front of the first dedication, but addressed to the same man, Giovanni Bernardino Bonifacio, Marquis of Oria. ${ }^{66}$ Terracina gives a short history of her decision to have her work printed, describing the steps she took to ready it for the press:

wishing to send it out, I wanted it first washed in the sweet fountain of Messer Lodovico so that more boldly, with any roughness left aside, it was not offered impolite and ill-composed into your presence. My plan did not succeed, for although it remained in his hands for more than a year, not only did it not taste any sweetness, but it imbibed so much bitter poison [Tuscan], that it caused others pain. . . . I wanted,

65 “credo vi sia noto quanto dispiacere habbia e con giusta cagione preso di Messer Lodovico Dolce, dolce forse ad altrui a me amarissimo, perciò che havendomi per più sue lettere offerto, voler egli haver pensiero di correggere la mia terza opera data in luce sopra i canti d'Ariosto, non solo non l'ha punto corretta ma Dio il volesse (con sua pace parlando) che fusse almeno di quel medesimo modo ch'io la mandai \& non di peggiore stampata" (Quarte rime, f.2.r.).

${ }^{66}$ Later forced to flee Naples as a heretic, the Marchese was a colorful character. See the entry, "Bonifacio, Giovanni Bernardino," in the Dizionario Biografico degli Italiani. 
without the corrections of others, to submit it to my own light revision and simply to purge it of the most unacceptable errors. ${ }^{67}$

Beneath the florid Renaissance prose lies a stark denunciation of Lodovico Dolce as an editor. The play on the double meaning of "Tosco" as "Tuscan" or poison, hints at the depth of Terracina's anger. Not only was Dolce's delay in looking over the work unreasonable, but he even seems to have failed at the task of improving its language and style.

The fact that this anger remains entirely concealed and unknown in the earlier editions of the Discorso is perhaps unsurprising, given Terracina's position as a female author. In later editions, however, she has found her voice to such an extent that she can even address Dolce scathingly in her poetry. At the start of the 1566 edition $^{68}$ of the Discorso, the first dedication to Giovan Bernardino Bonifacio is followed by a poem addressed to "M. Lodovico Dolce":

Ecco il Discorso, pur Dolce gentile,

In fretta da me visto, e non d'altrui,

67 “volendola mandar fuori, desiderai che prima si bagnasse nel dolce fonte di Messer Lodovico Dolce a tal che più baldanzosamente, lasciata da canto la ruvidezza, non si havesse ad offerire cosi impolita e mal composta, nel co[n]spetto [sic] di Vostro Signore Illustrissimo. Ne mi riuscì il dissegno [sic], che oltra che stette in suo potere per spatio di un'anno, non solamente nulla gustò di dolcezza, ma bevette tanto d'amaro tosco che ben è stata cagione di altrui di pena ... ho voluto senza altrui corretione porla sotto la mia leggera emenda e solamente purgarla dalli più biasimevoli errori” (Discorso [1566], 5-6).

${ }^{68}$ Printed and bound with the Rime, as held in Cambridge University Library, Bute.861. This additional dedication is found as early as the 1551 Giolito edition. 
E se la lingua mia fu si virile,

Perdon vi chieggio; e s'arrogante fui,

Ch'io non sapea se'l vero feminile

Fosse degno apparir dinanzi a vui.

Per sodisfatto ho al fin col mio sudore

A le vostre promesse, et al mio honore (Discorso [1566], 6)

(Here is the Discorso, noble Dolce,

Seen briefly by me and no other,

And if my language was so virile,

I ask your pardon; and if I was arrogant,

It was because I did not know if feminine truth

Was worthy of appearing before you.

I have, however, finally fulfilled with my sweat

Your promises, and my honor.)

Her tone is falsely modest, denigrating the Discorso as a hurried work that pushes at the accepted bounds of femininity. The final two lines, which juxtapose the highly masculine image of sweat and toil with proud female honor, are a rebuke to Dolce's broken "promesse." Such a public indictment of Dolce's tardiness would surely not have been undertaken lightly, and signal the extent to which Terracina is willing to take ownership of her own work.

\section{Conclusion: Terracina as a Mature Author}

As Terracina matured as an author, her editors seem to have played less prominent roles in presenting her work to the reading public. References to editors come in letters signed by the poet, implying she controlled the extent of their exposure. Of particular interest is her work with Giovanni Alfonso Mantegna di Maida. He first appears as a dedicatee, correspondent, 
and editor in Terracina's Quarte rime (1550), but the warm tone of their exchanges suggests that their professional friendship had been unfolding for some time. As we have seen, it was to Maida that Terracina explained the debacle with Dolce in the dedication to the Quarte rime, and laid out her reasons for preferring Maida's editorial work: "you have so well observed the Tuscan language and the beauty of expression." 99 Terracina is particularly interested in his proficiency in Tuscan, suggesting her awareness of its prestige as well as of her own status as a Neapolitan author. ${ }^{70}$

In the Quinte rime (1552), their relationship is exposed further when, in a lengthy endnote, Terracina flatteringly asserts that it is his skill that allows her to publish once more:

Since after I brought my fourth book of rime to light . . . I decided I did not want to send out any more things which might be seen in print . . . Thus I reasonably concluded in my mind that if they had to be sent out, they would come to be polished first in the realm of your wise and clear judgment. ${ }^{71}$

Mantegna's response comes in a lengthy piece of prose $(62 \mathrm{r}-69 \mathrm{v})$, in which he picks up on the theme of "Amore" to elaborate on the joys and sufferings of the Petrarchan lover, the role

69 "havete si bene la Toscana lingua e la vaghezza del dire osservata." (Quarte rime, f.2.v.)

${ }^{70}$ For more on the Questione della lingua and the Tuscanization of literary Italian, see Paolo Trovato, Il primo Cinquecento (Bologna: Il Mulino, 1994).

71 "Imperoche dipoi . . . che diedi in luce le mie quarte rime, deliberai non voler più mandar fuora, cosa che'n stampa si vedesse ... Dunque ho ragionevolmente conchiuso nell'animo c'havendo elle ad uscir fuora, vengano prima a farsi chiare nel cospetto del vostro maturo e candido giuditio" (Quinte rime, 61r-v). 
he chooses for himself, with some praise of Terracina. Unique in Terracina's work, this dense passage demonstrates not only her engagement in literary circles, but her interest in cultural fashions of the day, such as Petrarchism. ${ }^{72}$

Although after Mantegna, Terracina does not seem to have had a close relationship with any other editors, this is perhaps not surprising given the debacle of the Seste rime in 1558. When, in 1560, she published the authorized version of the Seste rime, it was with Raymondo Amato, a local Neapolitan publisher. This was also the strategy she used with the Settime rime, published by Mattio Cancer in Naples and addressed to local widows. The None rime present a different case again: the dedicatory letter, addressed to Don Ferrante, Cardinale de' Medici, was signed from Chiaia, but its purview was broader than just Naples. Within the collection, for example, is poetry addressed to Pope Gregory XIII, and it is fair to assume that the religious tenor of the work would have appealed across the Italian peninsula. Had the collection been published, its readership would have stretched well beyond Naples. The date of Terracina's death is unknown, but it seems probable that she died shortly after signing the 1577 dedication, preventing publication. Indeed, the fact that there was no posthumous publication, despite the autograph dedicatory letter showing that the author intended it to reach the press, suggests how important Terracina's own agency was in seeing her work into print.

Overall, it is clear that Laura Terracina took a far more active and decisive role in the publication of her eight printed texts than is usually acknowledged and, it seems fair to assume, would have done the same with the ninth book, if possible. Rather than a puppet in the hands of authoritative male editors, she was an increasingly important figure, not only in

${ }^{72}$ Poetry both to and from Maida is common in the Quarte rime, the Quinte rime and the Seste rime. 
ensuring that her works reached the press, but also in the presentation of texts to the reading public. When examining her Terracina's works, there can be no doubt that the poet felt ownership of the collection and an interest in the reader's response. Her relationships with her male editors also illuminate the pathways of publication in the Cinquecento, demonstrating how authors sought out editors and publishers who would respond to their needs, and possibly alleviate their own weaknesses. Much work remains to be done to understand how women in particular found pathways to print their work, paying attention to their role in the process rather than perceiving it as a one-sided search on the part of poligrafi for potentially fashionably female authors. The consideration of Terracina's oeuvre is an important step towards painting a fuller picture of women's participation in the world of publication and print. 